\title{
Swine carcasses classified by degree of exudation and marbling content
}

\author{
Teresinha Marisa Bertol(1), Arlei Coldebella(1), Jonas Irineu dos Santos Filho(1) and Antonio Lourenço Guidoni( ${ }^{(2)}$ \\ (1)Embrapa Suínos e Aves, BR-153, Km 110, Distrito de Tamanduá, Caixa Postal 321, CEP 89715-899 Concórdia, SC, Brazil. E-mail: \\ teresinha.bertol@embrapa.br, arlei.coldebella@embrapa.br, jonas.santos@embrapa.br ${ }^{(2)}$ In memoriam.
}

\begin{abstract}
The objective of this work was to develop and evaluate prediction equations, based on measurements obtained on the slaughter line, for carcass classification according to the degree of exudation and the content of marbling. A total of 747 pig carcasses originated from 27 producers were randomly selected on the slaughter line at two slaughterhouses, constituting representative samples from each one. Hot carcass weight, loin depth, back fat thickness, and $\mathrm{pH}$ and temperature $45 \mathrm{~min}$ after slaughter were used to generate the equations. The carcasses were classified as normal or exudative for drip loss of loin and ham, and as acceptable or undesirable for marbling content. For drip loss of loin and ham, respectively, the overall correct classification of the carcasses was 87.3 and $76.8 \%$, using the discriminant functions, for both categories. For marbling, the overall correct classification was $67.2 \%$, and only $69 \%$ of the carcasses were correctly classified as acceptable (marbling $>1$ ). The equations developed based on the measurements obtained on the slaughter line allow classifying swine carcasses with high accuracy, according to the degree of exudation, but not with the content of marbling.
\end{abstract}

Index terms: drip loss, ham, loin, pigs, prediction equations.

\section{Carcaças suínas classificadas por grau de exsudação e conteúdo de marmoreio}

Resumo - O objetivo deste trabalho foi desenvolver e avaliar equações de predição, baseadas em medidas obtidas na linha de abate, para classificação de carcaças suínas de acordo com o grau de exsudação e o conteúdo de marmoreio. Um total de 747 carcaças suínas, provenientes de 27 produtores, foi selecionado ao acaso na linha de abate, em dois abatedouros, tendo constituído amostras representativas de cada um. Para gerar as equações, foram utilizados peso da carcaça quente, profundidade do lombo, espessura de toucinho, e $\mathrm{pH}$ e temperatura medidos 45 min após o abate. As carcaças foram classificadas em normais ou exsudativas, quanto à perda por gotejamento do lombo e do pernil, e em aceitáveis ou indesejáveis, quanto ao marmoreio. Para a perda por gotejamento do lombo e do pernil, respectivamente, a classificação correta global das carcaças foi de 87,3 e 76,8\%, a partir das funções discriminantes, para ambas as categorias. Para o marmoreio, a classificação correta global foi de $67,2 \%$, e apenas $69 \%$ das carcaças foram classificadas corretamente como aceitáveis (marmoreio $>1$ ). As equações desenvolvidas com base nas medidas obtidas na linha de abate permitem classificar com elevada acurácia as carcaças suínas, de acordo com o grau de exsudação, mas não com o conteúdo de marmoreio.

Termos para indexação: perda por gotejamento, pernil, lombo, porcos, equações de predição.

\section{Introduction}

Drip loss and marbling are characteristics of economic importance for the pork industry, but are hard to evaluate routinely, because samples from high-value cuts are required and these results are only obtained 48 or 72 hours after slaughter. These measurements are, therefore, destructive and time consuming, increasing the interest in their prediction, which would enable segregating carcasses into quality classes with specific traits for high-quality and value products, besides minimizing losses by giving low-quality pork a proper destination.

Many efforts have been made to develop methods to predict pork quality defects. Light reflection- and electrical conductivity-based systems (Garrido et al., 1995), $\mathrm{pH}$ measured at $45 \mathrm{~min}$ or 24 hours after slaughter, and the degree of lightness ( $\mathrm{L}^{*}$ ) (Kusec et al., 2003) were evaluated with limited success to identify pale, soft, and exudative (PSE), as well as dark, firm, and dry (DFD), meat. The best results were found by Kauffman et al. (1993), who used several 
different instruments to predict meat quality, obtaining $82 \%$ correct classification. However, in general, these attempts have only been relatively successful and, in some cases, have used unfeasible slaughter line measurements, some of which were taken 24 hours after slaughter, making it impossible to classify the carcasses in a timely manner and to earmark them for specific products. More recently, other technologies - including low frequency dielectric spectra (CastroGiráldez et al., 2010), near-infrared reflectance spectroscopy (NIR) (Liao et al., 2010; Kapper et al., 2012; Neyrinck et al., 2015; Li et al., 2016;), NIR hyperspectral imaging (Barbin et al., 2012), and computer vision system (Chmiel et al., 2011, 2016) - were investigated as tools for the prediction and classification of carcasses according to pork quality, with some promising results. However, most of these studies involved sample collection from carcasses and analyses at the laboratory level, not on the slaughter line at the industrial level.

Previous studies have shown a direct association between the size of the loin eye area and the degree of exudation of pig carcasses (Fischer, 2007), besides a negative association between genetic selection for improved lean meat production and meat quality attributes (Gilbert et al., 2007), suggesting that pigs intensively selected for lean meat production tend to show poorer meat quality.

The objective of this work was to develop and evaluate prediction equations, based on measurements obtained on the slaughter line, for carcass classification according to the degree of exudation and the content of marbling.

\section{Materials and Methods}

A total of 747 pig carcasses were randomly selected on the slaughter line at two slaughterhouses located in the states of Santa Catarina and Rio Grande do Sul, Brazil: 507 carcasses, originated from 17 producers, at slaughter plant 1; and 240 carcasses, originated from 10 producers, at slaughter plant 2 . The carcasses were randomly selected from each producer, taking into account the gender and genotype of the pigs delivered in each specific day, in order to include, in the sampling, the three pig genders and major genotypes produced in the agricultural industry where the samples were collected. At slaughter plant 1, carcasses were from four genotypes and three genders: gilts and both physically and immunologically castrated barrows; and, at slaughter plant 2, from three genotypes and two genders: females and immunologically castrated barrows. Overall, these genotypes are representative of the genetic material used in the country for industrial pork production. Data were collected for eight days at slaughter plant 1 and for five days at slaughter plant 2 .

The distance from the farms to the slaughterhouses varied from 21 to $205 \mathrm{~km}$. The pigs were transported from the former to the later in trucks with two floors, compartments for six animals, and space allowance of $0.425 \mathrm{~m}^{2} 100 \mathrm{~kg}^{-1}$. The pigs were subjected to pre-slaughter fasting of 18 hours and lairage time of 3 hours, and were bled in the horizontal position following stunning by electronarcosis. After bleeding, the pigs were subjected to the industry standard processes of scalding, depilation, scorching, dressing, and evisceration. Following evisceration, back fat and loin depth were measured with the use of an electronic grading probe: an optical Fat-o-Meat'er (Carometec Food Technology, Smørum, Denmark), at slaughter plant 1; and an ultrasound Hennessy probe (Hennessy Grading Systems, Auckland, New Zealand), at slaughter plant 2. Hot carcass weight was then obtained, after which the carcasses were moved to the chilling room where they remained stored at 2 to $4^{\circ} \mathrm{C}$ for 24 hours. The measurements were taken between the third and fourth ribs, $6 \mathrm{~cm}$ from the midline, at both slaughterhouses.

After slaughter, marbling score, drip loss, and $\mathrm{pH}$ and temperature $45 \mathrm{~min}$ after slaughter ( $\mathrm{pH} 45$ and Temp45, respectively) were measured in the longissimus thoracis muscle at the last rib and in the semimembranosus muscle at the medial side. $\mathrm{pH}$ was measured by insertion of a FC 232D electrode for meat (Hanna Instruments Brasil, Barueri, SP, Brazil), coupled to a HI 99163 portable $\mathrm{pH}$ meter (Hanna Instruments Brasil, Barueri, SP, Brazil). Drip loss was evaluated considering the difference between the initial and final weights of 8 to 12 -g cylindrical samples, which were placed in containers with a column for collecting exudate and kept refrigerated at 2 to $4^{\circ} \mathrm{C}$ for 48 hours, without contacting the exudate (Correa et al., 2007).

All the assessed variables are continuous, except marbling score, which assumes ordinal categories ranging from 1 to 10 (Berg, 2000). Data were analyzed 
using the statistical software SAS (SAS Institute Inc., Cary, NC, USA), according to the following steps. First, a statistical descriptive summary of all variables was done to understand their distribution in the sample. Second, classification variables were generated for each meat quality attribute, comprising the categories for drip loss of loin, drip loss of ham, and marbling, adopting the following arbitrary values : normal if $0<$ drip loss $\leq 6 \%$ or exudative if drip loss $>6 \%$ for loin; normal if $0<$ drip loss $\leq 4 \%$ or exudative if drip loss $>4 \%$ for ham; and undesirable if marbling $=1$ or acceptable if marbling $>1$. Third, the correlation between the predictor variables was studied, using the Corr procedure of SAS to calculate two-by-two Pearson's correlation. Fourth, the analysis of variance was used to compare the categories within each meat quality attribute and to check which variables cause the differences between them by the GLM procedure of SAS. Fifth, prediction equations were developed for carcass classification through the discriminant functions and the consistency analysis of carcass classification, using the Discrim and Freq procedures of SAS, respectively. Lastly, regression equations were used to predict raw drip loss with the REG procedure of SAS, carcass classification based on the predicted values, and the consistency analysis of carcass classification according to this method, which is an alternative to discriminant functions, allowing for improved agreement in a specific category of interest.

\section{Results and Discussion}

The data showed considerable variation in the weight, muscularity, and meat quality of the carcasses (Table 1). Therefore, it is estimated that the variability required for this type of study was obtained in the predicted and predictor variables, since a high variation in the data set is favorable for developing prediction equations.

All correlations were significant $(\mathrm{p}<0.05)$ except those between back fat thickness and Temp45 of loin, Temp45 of ham, and pH45 of ham, and those between hot carcass weight and Temp45 of loin and Temp45 of ham (Table 2). Therefore, the hypothesis of independence between the candidate variables was discarded, which refers to the use of multivariate discriminant functions to estimate the equations for carcass classification.
Carcasses were tentatively classified according to drip loss, considering the Berg (2000) guidelines, as: DFD meat, when drip loss $\leq 2 \%$; normal meat, when $>2 \%$ drip loss $\leq 6 \%$; and reddish pink, soft, and exudative (RSE) or PSE meat, when drip loss $>6 \%$. However, in the group of carcasses with drip loss $\leq 2 \%$ (74 carcasses), only two carcasses showed luminosity ( $\mathrm{L}^{*}$ value) $\leq 38$ and ten had $\mathrm{pH} 45>6.80$, which are also indicators of DFD meat. Therefore, drip loss $<2 \%$ did not necessarily mean DFD meat. For this reason and due to the low number of carcasses falling into this range, it was not possible to adjust any equation based on three categories; therefore, two classes were adopted: normal, if drip loss of loin $\leq 6 \%$; and exudative, if drip loss $>6 \%$.

The differences in the carcass and meat quality traits were highly significant $(\mathrm{p}<0.005$ to $\mathrm{p}<0.0001)$ between the categories of drip loss and of marbling, except for the back fat thickness in the category of drip loss of ham (Table 3). The carcasses classified as normal regarding the attribute drip loss showed greater average weight, back fat thickness, and $\mathrm{pH} 45$, besides lower loin depth and Temp45. The carcasses classified as acceptable for marbling content had lower average weight, loin depth, and Temp45, but greater back fat thickness and $\mathrm{pH} 45$. Therefore, there is a clear difference between the discretionary categories, showing a negative association between the degree of muscularity and meat quality. These results agree with

Table 1. Descriptive summary of the pig carcass and meat quality traits.

\begin{tabular}{lccccc}
\hline Variable & Number & Mean & SD & Minimum Maximum \\
\hline \multicolumn{5}{c}{ Carcass traits } \\
HCW (kg) & 746 & 98.79 & 12.36 & 45.80 & 132.60 \\
BFT (mm) & 745 & 18.01 & 5.30 & 6.40 & 36.80 \\
Loin depth (mm) & 744 & 58.74 & 8.29 & 38.70 & 89.20 \\
\hline \multicolumn{5}{c}{ Meat quality traits for loin } \\
pH45 ${ }^{(1)}$ & 746 & 6.34 & 0.22 & 5.64 & 7.05 \\
Temp45 $\left({ }^{\circ} \mathrm{C}\right)^{(2)}$ & 747 & 27.01 & 4.12 & 15.30 & 34.90 \\
Marbling score ${ }^{(3)}$ & 743 & 1.91 & 0.83 & 1.00 & 4.00 \\
Drip loss $(\%)$ & 745 & 5.98 & 3.39 & 0.40 & 16.03 \\
\hline & 747 & 6.42 & 0.21 & 5.72 & 7.12 \\
pH45 & 747 & 27.08 & 4.22 & 15.50 & 34.90 \\
Temp45 ( $\left.{ }^{\circ} \mathrm{C}\right)$ & 746 & 3.63 & 2.10 & 0.24 & 15.53 \\
Drip loss $(\%)$ & \multicolumn{5}{c}{ Meat quality traits for ham }
\end{tabular}

(1) $\mathrm{pH} 45, \mathrm{pH} 45 \mathrm{~min}$ after slaughter. ${ }^{(2)} \mathrm{Temp} 45$, temperature $45 \mathrm{~min}$ after slaughter. ${ }^{(3)}$ Marbling scoring system according to Berg (2000): 1, devoid to practically devoid, ...; and 10, abundant. SD, standard deviation; $\mathrm{HCW}$, ot carcass weight; BFT, back fat thickness. 
the findings of Fischer (2007), who reported that pigs with greater loin eye area produced more exudative carcasses than those with smaller loin eye area. The differences observed for hot carcass weight, back fat thickness, loin depth, and $\mathrm{pH}$ between the normal and exudative carcasses, as well as between the acceptable and undesirable ones, may be attributed to the genetic selection for improved feeding efficiency and lean meat production, which leads to a reduction in intramuscular fat content, impairs other meat quality attributes (Gilbert et al., 2007), and increases the proportion of glycolytic fibers (Brocks et al., 2000) and the fiber diameter in the muscles (Lefaucheur et al., 2011). White glycolytic fibers have less blood vascularization, lower content of myoglobin, and a primarily glycolytic metabolism (Judge et al., 1989), which favors the anaerobic metabolism in muscle by the acidification of body fluids. These studies show that pigs intensively selected for increased lean meat content tend to have leaner carcasses, but with poorer meat quality, which is also observed among individuals with different degrees of muscularity within the same genetic group. This partly explains the negative association found in the present study between the variables indicative of muscularity and meat quality.

The negative association between muscle temperature and/or between initial $\mathrm{pH}$ and drip loss has been previously reported (Fisher, 2007; Choi et al., 2010). The main causes are muscle protein denaturation and shrinkage caused by the combination of warm muscle (close to body temperature) and $\mathrm{pH}$ bellow 6.0, expelling the water from the cell (Huff-Lonergan

Table 2. Correlation structure (r) between the variables that potentially explain the categories used to group the pig carcasses $(\mathrm{n}=746)$ according to meat quality ${ }^{(1)}$.

\begin{tabular}{|c|c|c|c|c|c|c|}
\hline Variable $^{(2)}$ & $\begin{array}{l}\text { Hot carcass } \\
\text { weight }(\mathrm{kg})\end{array}$ & $\begin{array}{c}\text { Back fat } \\
\text { thickness (mm) }\end{array}$ & $\begin{array}{l}\text { Loin depth } \\
\text { (mm) }\end{array}$ & pH45 of loin & $\begin{array}{c}\text { Temp45 of loin } \\
\left({ }^{\circ} \mathrm{C}\right)\end{array}$ & pH45 of ham \\
\hline Back fat thickness (mm) & 0.394 & & & & & \\
\hline Loin depth (mm) & 0.133 & -0.324 & & & & \\
\hline $\mathrm{pH} 45$ of loin & 0.092 & 0.083 & -0.221 & & & \\
\hline Temp45 of loin $\left({ }^{\circ} \mathrm{C}\right)$ & -0.058 & 0.005 & 0.314 & -0.406 & & \\
\hline $\mathrm{pH} 45$ of ham & 0.082 & 0.059 & -0.128 & 0.685 & -0.182 & \\
\hline Temp45 of ham $\left({ }^{\circ} \mathrm{C}\right)$ & -0.058 & 0.002 & 0.311 & -0.403 & 0.985 & -0.189 \\
\hline
\end{tabular}

${ }^{(1)}$ If $|r| \geq 0.08$, the value of correlation differs significantly from zero by Student's t-test, at $5 \%$ probability. ${ }^{(2)} \mathrm{pH} 45$ and Temp $45, \mathrm{pH}$ and temperature 45 min after slaughter, respectively.

Table 3. Analysis of variance of the carcass and meat quality traits measured in the carcasses $(n=746)$, in order to compare the categories of drip loss and of marbling (mean \pm standard error).

\begin{tabular}{|c|c|c|c|c|c|}
\hline Category & $\begin{array}{l}\text { Hot carcass weight } \\
(\mathrm{kg})\end{array}$ & $\begin{array}{l}\text { Back fat thickness } \\
(\mathrm{mm})\end{array}$ & $\begin{array}{l}\text { Loin depth } \\
(\mathrm{mm})\end{array}$ & $\mathrm{pH} 45^{(4)}$ & $\begin{array}{c}\text { Temp } 45^{(4)} \\
\left({ }^{\circ} \mathrm{C}\right)\end{array}$ \\
\hline & \multicolumn{5}{|c|}{ Drip loss of loin } \\
\hline Normal $^{(1)}$ & $100.1 \pm 0.55$ & $18.64 \pm 0.28$ & $56.03 \pm 0.34$ & $6.45 \pm 0.01$ & $24.82 \pm 0.16$ \\
\hline Exudative $^{(1)}$ & $97.14 \pm 0.75$ & $17.19 \pm 0.24$ & $62.40 \pm 0.48$ & $6.20 \pm 0.01$ & $29.99 \pm 0.17$ \\
\hline \multirow[t]{2}{*}{ P-value } & 0.0010 & 0.0002 & $<0.0001$ & $<0.0001$ & $<0.0001$ \\
\hline & \multicolumn{5}{|c|}{ Drip loss of ham } \\
\hline Normal $^{(2)}$ & $99.79 \pm 0.53$ & $18.26 \pm 0.26$ & $57.28 \pm 0.35$ & $6.48 \pm 0.01$ & $25.62 \pm 0.18$ \\
\hline Exudative $^{(2)}$ & $97.15 \pm 0.81$ & $17.58 \pm 0.28$ & $61.35 \pm 0.54$ & $6.32 \pm 0.01$ & $29.65 \pm 0.20$ \\
\hline \multirow[t]{2}{*}{ P-value } & 0.0050 & 0.0936 & $<0.0001$ & $<0.0001$ & $<0.0001$ \\
\hline & \multicolumn{5}{|c|}{ Marbling } \\
\hline Undesirable $^{(3)}$ & $96.54 \pm 0.83$ & $16.64 \pm 0.29$ & $61.38 \pm 0.51$ & $6.28 \pm 0.01$ & $27.83 \pm 0.27$ \\
\hline Acceptable $^{(3)}$ & $99.89 \pm 0.52$ & $18.71 \pm 0.25$ & $57.32 \pm 0.36$ & $6.38 \pm 0.01$ & $26.56 \pm 0.18$ \\
\hline P-value & 0.0004 & $<0.0001$ & $<0.0001$ & $<0.0001$ & $<0.0001$ \\
\hline
\end{tabular}

${ }^{(1)}$ Categories: normal if $0<$ drip loss $\leq 6$; and exudative if drip loss $>6$. ${ }^{(2)}$ Categories: normal if $0<$ drip loss $\leq 4$; and exudative if drip loss $>4$. ${ }^{(3)}$ Categories: undesirable if marbling $=1$; and acceptable if marbling $>1$. ${ }^{(4)}$ In the categories of drip loss of loin and of marbling, $\mathrm{pH}$ and temperature of loin $45 \mathrm{~min}$ after slaughter ( $\mathrm{pH} 45$ and Temp45, respectively) were compared, while, in the categories of drip loss of ham, $\mathrm{pH} 45$ and Temp45 of ham were compared. 
\& Lonergan, 2007), although initial $\mathrm{pH}$ values $\leq 6.2$ have also been associated with exudative carcasses (Fisher, 2007). As for the marbling attribute, despite the evident association with $\mathrm{pH} 45$, it is not believed to constitute a cause and effect relationship.

The linear discriminant functions for carcass classification were generated using: $\mathrm{pH}$ and temperature of loin for the categories of drip loss and marbling of loin; and $\mathrm{pH}$ and temperature of ham for drip loss of ham. The obtained equations were:

$-26.744+0.028 \mathrm{HCW}+0.018 \mathrm{BT}-0.09 \mathrm{LD}+$ $6.575 \mathrm{pH} 45$ - 0.446 Temp45 for drip loss of loin;

$-15.054+0.017 \mathrm{HCW}-0.009 \mathrm{BT}-0.036 \mathrm{LD}+$ $3.669 \mathrm{pH} 45-0.263 \mathrm{Temp} 45$ for drip loss of ham; and

$-8.158+0.021 \mathrm{HCW}+0.03 \mathrm{BT}-0.054 \mathrm{LD}+1.52 \mathrm{pH} 45$ - 0.011Temp45 for marbling,

in which $\mathrm{HCW}$ is the hot carcass weight, BT is back fat thickness, LD is loin depth, $\mathrm{pH} 45$ is the $\mathrm{pH} 45 \mathrm{~min}$ after slaughter, and Temp45 is the temperature $\left({ }^{\circ} \mathrm{C}\right) 45$ min after slaughter.

Based on the result of each function, the carcass was classified as: normal or acceptable, when the value was greater than 0 ; exudative or undesirable, when the value was lower than zero; or undefined, when equal to 0 .

For drip loss of loin, the consistency analysis of the discriminant functions correctly classified $89.3 \%$ of the carcasses in the normal category and showed an overall correct classification of $87.3 \%$ in both categories (Table 4). In other words, among the carcasses classified as normal by the discriminant function, $89.3 \%$ agree with the classification by the conventional assessment of drip loss $\leq 6 \%$. For drip loss of ham, overall correct classification using the discriminant function was $76.8 \%$, which was lower than that observed in the loin. In this case, $81.4 \%$ of the carcasses actually fit in the normal category according to the conventional assessment drip loss $\leq 4 \%$. For marbling, the degree of overall correct classification was $67.2 \%$, and only $69 \%$ of carcasses were correctly classified as acceptable (marbling $>1$ ).

The adjusted regression equations for predicting drip loss of loin and ham were developed with the same predictor variables used for the discriminant functions, fitting the regression equations directly to the raw data (without categorization) and classifying the carcasses using the estimated values. This method is useful to improve the proportion of correct classification in a specific category of interest. The estimated regression equations were as follows:

$-54.644-0.019 \mathrm{HCW}-0.730 \mathrm{BT}+0.070 \mathrm{LD}+$ $7.629 \mathrm{pH} 45+4.213 \mathrm{Temp} 45-0.608 \mathrm{pH} 45 \times \mathrm{Temp} 45+$ $0.116 \mathrm{BT} \times \mathrm{pH} 45$ for drip loss of loin; and

$$
-22.109+0.046 \mathrm{HCW}+0.014 \mathrm{LD}+2.368 \mathrm{pH} 45+
$$
$1.783 \mathrm{Temp} 45-0.215 \mathrm{pH} 45 \times$ Temp45 $-0.002 \mathrm{HCW} \times$ Temp45 for drip loss of ham,

with regression coefficients $\left(\mathrm{R}^{2}\right)$ of 0.66 and 0.35 , respectively.

Table 4. Consistency analysis of pig carcass classification by drip loss and marbling using the discriminant functions.

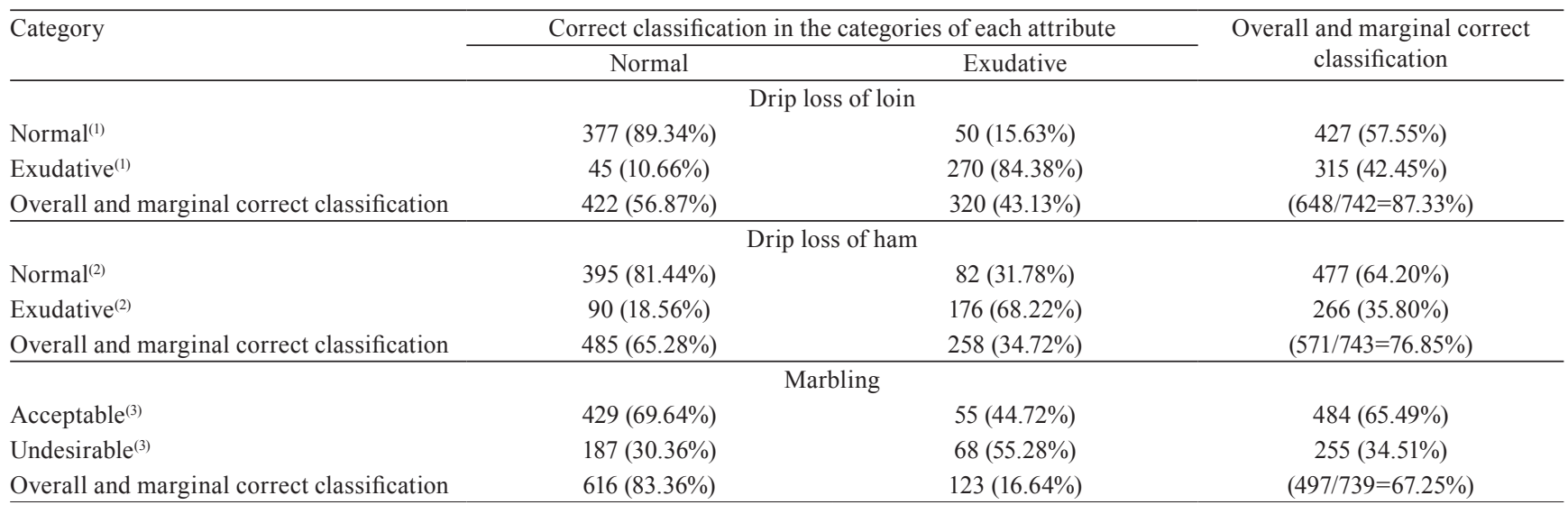

${ }^{(1)}$ Categories: normal if $0<$ drip loss $\leq 6$; and exudative if drip loss $>6$. ${ }^{(2)}$ Categories: normal if $0<$ drip loss $\leq 4$; and exudative if drip loss $>4$. ${ }^{(3)}$ Categories: undesirable if marbling $=1$; and acceptable if marbling $>1$. 
A regression equation could not be adjusted to predict marbling due to the scale of this variable, which is not continuous. Although the $\mathrm{R}^{2}$ of the equation for predicting drip loss of loin was modest and the one for predicting drip loss of ham was low, it should be pointed out that this indicator only measures the quality of the prediction adjustments of this attribute. The most important is the percentage of correct classification, which is given by the consistency analysis.

The carcasses were classified based on the estimated value for each attribute by the adjusted regression equation. The overall correct classification of carcasses in the categories of drip loss, using the adjusted regression equation, was $85.4 \%$, which is slightly lower than that obtained using the discriminant function; however, the correct classification of carcasses in the normal category was $89.97 \%$, similar to the rate obtained with the discriminant function (Table 5). Consistency analyses with different limiting values for drip loss were also performed. When the limiting value of the estimated drip loss of loin was changed to $5 \%$ for the normal category, the correct classification increased to $92.7 \%$; however, the overall agreement was lowered due to increased erroneous carcass classification in the exudative category. This change in the estimated limiting value for carcass classification, despite resulting in an increased overall error, is useful for increasing the correct classification in the category defined as the most important.
The correct carcass classification in the normal category of drip loss of ham $\leq 4 \%$ was $82.1 \%$, whereas the overall agreement was $75.8 \%$. By repeating the consistency analysis using the limiting value of $\leq 3.5 \%$ estimated for drip loss of ham for the normal category, the correct classification in this category rose to $87.6 \%$, while the overall agreement fell, due to the increased erroneous carcass classification in the exudative category.

Water retention in the muscle depends on complex mechanisms of chemical and structural nature (HuffLonergan \& Lonergan, 2007). Several variables, in addition to those measured in the present study, may affect muscle drip loss, although initial $\mathrm{pH}$ and temperature of the carcasses are among the most important ones. Fisher (2007) found that $75 \%$ of the carcasses considered exudative and non-exudative had an initial $\mathrm{pH}$ lower and higher than 6.2, respectively, meaning that other factors, besides initial $\mathrm{pH}$, affect muscle water-holding capacity. These factors include final $\mathrm{pH}$ (Juncher et al., 2001), degree of sarcomere shortening (Huff-Lonergan \& Lonergan, 2007), specific protein denaturation (Huff-Lonergan \& Lonergan, 2007; Choi et al., 2010), oxidation and subsequent aggregation of myofibrillar proteins (Traore et al., 2012). This may explain why, even though all the explanatory variables of the variations in drip loss were not evaluated in the present study, a high degree of success was achieved in carcass classification. It

Table 5. Consistency analysis of pig carcass classification by drip loss using the adjusted regression equations, varying the threshold of the estimated value of drip loss in the normal category.

\begin{tabular}{|c|c|c|c|}
\hline \multirow[t]{2}{*}{ Category } & \multicolumn{2}{|c|}{ Correct classification in the categories } & \multirow{2}{*}{$\begin{array}{l}\text { Overall and marginal correct } \\
\text { classification }\end{array}$} \\
\hline & Normal & Exudative & \\
\hline \multicolumn{4}{|c|}{ Loin, drip loss $\leq 6 \%$} \\
\hline Normal & $359(89.97 \%)$ & $68(19.83 \%)$ & $427(57.55 \%)$ \\
\hline Exudative & $40(10.03 \%)$ & $275(80.17 \%)$ & $315(42.45 \%)$ \\
\hline Overall and marginal correct classification & $399(53.77 \%)$ & $343(46.23 \%)$ & $(634 / 742=85.44 \%)$ \\
\hline \multicolumn{4}{|c|}{ Loin, drip loss $\leq 5 \%$} \\
\hline Normal & $305(92.71 \%)$ & $122(29.54 \%)$ & $427(57.55 \%)$ \\
\hline Exudative & $24(7.29 \%)$ & $291(70.46 \%)$ & $315(42.45 \%)$ \\
\hline Overall and marginal correct classification & $329(44.34 \%)$ & $413(55.66 \%)$ & $(596 / 742=80.32 \%)$ \\
\hline \multicolumn{4}{|c|}{ Ham, drip loss $\leq 4 \%$} \\
\hline Normal & $379(82.21 \%)$ & $98(34.75 \%)$ & $477(64.20 \%)$ \\
\hline Exudative & $82(17.79 \%)$ & $184(65.25 \%)$ & $266(35.80 \%)$ \\
\hline Overall and marginal correct classification & $461(62.05 \%)$ & $282(37.95 \%)$ & $(563 / 743=75.77 \%)$ \\
\hline \multicolumn{4}{|c|}{ Ham, drip loss $\leq 3.5 \%$} \\
\hline Normal & $317(87.57 \%)$ & $160(41.99 \%)$ & $477(64.20 \%)$ \\
\hline Exudative & $45(12.43 \%)$ & $221(58.01 \%)$ & $266(35.80 \%)$ \\
\hline Overall and marginal correct classification & $362(48.72 \%)$ & $381(51.28 \%)$ & $(538 / 743=72.31 \%)$ \\
\hline
\end{tabular}

Pesq. agropec. bras., Brasília, v.52, n.2, p.121-128, fev. 2017

DOI: 10.1590/S0100-204X2017000200006 
is possible that the initial $\mathrm{pH}$ between 6.2 and 6.0, although not low enough to cause the PSE condition, may induce, to some degree, problems such as protein denaturation, oxidation of proteins, and sarcomere shortening.

Genetic selection for increased lean gain has resulted in carcasses with lower back fat thickness and intramuscular fat content (Lefaucheur et al., 2011; Rauw et al., 2012). This shows that the degree of muscularity of the carcass could be an indicator of the marbling content. However, the buildup of marbling in the muscles of pigs is greatly affected by several factors, especially breed or genotype (Bertol et al., 2013), nutrition (Morel et al., 2008; Bertol et al., 2010; Olivares et al., 2011; Katsumata et al., 2012), slaughter weight (Latorre et al., 2003), and feed management. Furthermore, there seems to be no relationship between intramuscular fat and $\mathrm{pH}$. Therefore, the variables obtained on the slaughter line in the present study were not sufficient to compose a predictive equation for this trait in pigs.

Kapper et al. (2012) evaluated the development of prediction equations by NIR to classify carcasses in two classes of drip loss, according to meat quality: superior and inferior. The authors reported that the best equation provided an agreement of 72 and $77 \%$ for the classification of carcasses in the superior and inferior categories, respectively, which is lower than the correct classification obtained in the present study. Better results were found by Li et al. (2016) and Neyrinck et al. (2015) with the NIR technology to differentiate potential PSE and normal meat, reaching a correct classification of $93.3 \%$, as well as by Barbin et al. (2012), who used NIR hyperspectral imaging to obtain $96 \%$ correct classification of pork in the classes: PSE; reddish-pink, firm, and non-exudative; and DFD meat. Chmiel et al. (2011) showed that the computer vision system is efficient to detect potential PSE meat in the longissimus lumborum but not in the semimembranosus muscle (Chmiel et al., 2016); however, according to the authors, since these results were obtained by scanning samples at the laboratory level, it is necessary to develop a system with a nondestructive or time-consuming method that can be implemented online for commercial use.

In the present study, it is likely that the high accuracy of carcass classification by drip loss was possible due to the great variability in the weight, degree of muscularity, and meat quality attributes of the carcasses.

\section{Conclusion}

The equations developed based on the measurements obtained exclusively on the slaughter line allow classifying swine carcasses with high accuracy, according to the degree of exudation, but not with the content of marbling.

\section{References}

BARBIN, D.; ELMASRY, G.; SUN, D.-W.; ALLEN, P. Nearinfrared hyperspectral imaging for grading and classification of pork. Meat Science, v.90, p.259-268, 2012. DOI: 10.1016/j. meatsci.2011.07.011.

BERG, E. Pork composition \& quality assessment procedures. Des Moines: NPPC, 2000. 42p.

BERTOL, T.M.; CAMPOS, R.M.L. de; COLDEBELLA, A.; SANTOS FILHO, J.I. dos; FIGUEIREDO, E.A.P. de; TERRA, N.N.; AGNES, I.B.L. Qualidade da carne e desempenho de genótipos de suínos alimentados com dois níveis de aminoácidos. Pesquisa Agropecuária Brasileira, v.45, p.621-629, 2010. DOI: 10.1590/S0100-204X2010000600012.

BERTOL, T.M.; CAMPOS, R.M.L. de; LUDKE, J.V.; TERRA, N.N.; FIGUEIREDO, E.A.P. de; COLDEBELLA, A.; SANTOS FILHO, J.I. dos; KAWSKI, V.L.; LEHR, N.M. Effects of genotype and dietary oil supplementation on performance, carcass traits, pork quality and fatty acid composition of backfat and intramuscular fat. Meat Science, v.93, p.507-516, 2013. DOI: 10.1016/j.meatsci.2012.11.012.

BROCKS, L.; KLONT, R.E.; BUIST, W.; GREEF, K. de; TIEMAN, M.; ENGEL, B. The effects of selection of pigs on growth rate vs leanness on histochemical characteristics of different muscles. Journal of Animal Science, v.78, p.1247-1254, 2000. DOI: $10.2527 / 2000.7851247 x$.

CASTRO-GIRÁldEZ, M.; BOTELLA, P.; TOLDRÁ, F.; FITO, P. Low-frequency dielectric spectrum to determine pork meat quality. Innovative Food Science and Emerging Technologies, v.11, p.376-386, 2010. DOI: 10.1016/j.ifset.2010.01.011.

CHMIEL, M.; SLOWINSKI, M.; DASIEWICZ, K.; FLOROWSKI, T. Use of computer vision system (CVS) for detection of PSE pork meat obtained from $m$. semimembranosus. LWT - Food Science and Technology, v.65, p.532-536, 2016. DOI: 10.1016/j. lwt.2015.08.021.

CHMIEL, M.; SLOWINSKI, M.; DASIEWICZ, K. Lightness of the color measured by computer image analysis as a factor for assessing the quality of pork meat. Meat Science, v.88, p.566-570, 2011. DOI: 10.1016/j.meatsci.2011.02.014.

CHOI, Y.M.; LEE, S.H.; CHOE, J.H.; RHEE, M.S.; LEE, S.K.; JOO, S.T.; KIM, B.C. Protein solubility is related to myosin isoforms, muscle fiber types, meat quality traits, and postmortem 
protein changes in porcine longissimus dorsi muscle. Livestock Science, v.127, p.183-191, 2010. DOI: 10.1016/j.livsci.2009.09.009.

CORREA, J.A.; MÉTHOT, S.; FAUCITANO, L. A modified meat juice container (ez-driploss) procedure for a more reliable assessment of drip loss and related quality changes in pork meat. Journal of Muscle Foods, v.18, p.67-77, 2007. DOI: 10.1111/j.17454573.2007.00066.x.

FISHER, K. Drip loss in pork: influencing factors and relation to further meat quality traits. Journal of Animal Breeding and Genetics, v.124, p.12-18, 2007. Supplement 1. DOI: 10.1111/j.14390388.2007.00682.x.

GARRIDO, M.D.; PEDAUYÉ, J.; BAÑON, S.; LÓPEZ, M.B.; LAENCINA, J. On-line methods for pork quality detection. Food Control, v.6, p.111-113, 1995. DOI: 10.1016/0956-7135(95)98915-N.

GILBERT, H.; BIDANEL, J.-P.; GRUAND, J.; CARITEZ, J.C.; BILlON, Y.; GUIlloUET, P.; LAGANT, H.; NOBLET, J.; SELLIER, P. Genetic parameters for residual feed intake in growing pigs, with emphasis on genetic relationships with carcass and meat quality traits. Journal of Animal Science, v.85, p.31823188, 2007. DOI: $10.2527 /$ jas.2006-590.

HUFF-LONERGAN, E.; LONERGAN, S.M. New frontiers in understanding drip loss in pork: recent insights on the role of postmortem muscle biochemistry. Journal of Animal Breeding and Genetics, v.124, p.19-26, 2007. Supplement 1. DOI: 10.1111/j.1439-0388.2007.00683.x.

JUDGE, M.D.; ABERLE, E.D.; FORREST, J.C.; HEDRICK, H.B.; MERKEL, R.A. Principles of meat science. $2^{\text {nd }}$ ed. Iowa: Kendall/Hunt, 1989. 351p.

JUNCHER, D.; RONN, B.; MORTENSEN, E.T.; HENCKEL, P.; KARLSSON, A.; SKIBSTED, L.H.; BERTELSEN, G. Effect of pre-slaughter physiological conditions on the oxidative stability of colour and lipid during chill storage of pork. Meat Science, v.58, p.347-357, 2001. DOI: 10.1016/S0309-1740(00)00156-X.

KAPPER, C.; KLONT, R.E.; VERDONK, J.M.A.J.; WILIAMS, P.C.; URLINGS, H.A.P. Prediction of pork quality with near infrared spectroscopy (NIRS) 2. Feasibility and robustness of NIRS measurements under production plant conditions. Meat Science, v.91, p.300-305, 2012. DOI: 10.1016/j.meatsci.2012.02.006.

KATSUMATA, M.; KYOYA, T.; ISHIDA, A.; OHTSUKA, M.; NAKASHIMA, K. Dose-dependent response of intramuscular fat accumulation in longissimus dorsi muscle of finishing pigs to dietary lysine levels. Livestock Science, v.149, p.41-45, 2012. DOI: 10.1016/j.livsci.2012.06.025.

KAUFFMAN, R.G.; SYBESMA, W.; SMULDERS, F.J.M.; EIKELENBOOM, G.; ENGEL, B.; VAN LAACK, R.L.J.M.; HOVING-BOLINK, A.H.; STERRENBURG, P.; NORDHEIM, E.V.; WALSTRA, P.; WAL, P.G. van der. The effectiveness of examining early post-mortem musculature to predict ultimate pork quality. Meat Science, v.34, p.283-300, 1993. DOI: 10.1016/03091740(93)90078-V.
KUSEC, G.; KRALIK, G.; PETRICEVIC, A.; GUTZMIRTL, H.; GRGURIC, D. Meat quality indicators and their correlation in two crosses of pigs. Agriculturae Conspectus Scientificus, v.68, p.115-119, 2003.

LATORRE, M.A.; MEDEL, P.; FUENTETAJA, A.; LÁZARO, R.; MATEOS, G.G. Effect of gender, terminal sire line and age at slaughter on performance, carcass characteristics and meat quality of heavy pigs. Animal Science, v.77, p.33-45, 2003.

LEFAUCHEUR, L.; LEBRET, B.; ECOLAN, P.; LOUVEAU, I.; DAMON, M.; PRUNIER, A.; BILlON, Y.; SELlIER, P.; GILBERT, H. Muscle characteristics and meat quality traits are affected by divergent selection on residual feed intake in pigs. Journal of Animal Science, v.89, p.996-1010, 2011. DOI: 10.2527/ jas.2010-3493.

LI, X.; FENG, F.; GAO, R.; WANG, L.; QIAN, Y.; LI, C.; ZHOU, G. Application of near infrared reflectance (NIR) spectroscopy to identify potential PSE meat. Journal of the Science of Food and Agriculture, v.96, p.3148-3156, 2016. DOI: 10.1002/jsfa.7493.

LIAO, Y.-T.; FAN, Y.-X.; CHENG, F. On-line prediction of fresh pork quality using visible/near-infrared reflectance spectroscopy. Meat Science, v.86, p.901-907, 2010. DOI: 10.1016/j. meatsci.2010.07.011.

MOREL, P.C.H.; JANZ, J.A.M.; ZOU, M.; PURCHAS, R.W.; HENDRIKS, W.H.; WILKINSON, B.H.P. The influence of diets supplemented with conjugated linoleic acid, selenium, and vitamin E, with or without animal protein, on the composition of pork from female pigs. Journal of Animal Science, v.86, p.11451155, 2008. DOI: 10.2527/jas.2007-0358.

NEYRINCK, E.; DE SMET, S.; VERMEULEN, L.; TELLEIR, D.; LESCOUHIER, S.; PAELINCK, H.; FRAEYE, I.; GEERS, R.; RAES, K. Application of near-infrared spectroscopy for the classification of fresh pork quality in cooked ham production. Food Bioprocessing Technology, v.8, p.2383-2391, 2015. DOI: 10.1007/s11947-015-1583-z.

OLIVARES, A.; REY, A.I.; DAZA, A.; LÓPEZ-BOTE, C.J. Low levels of dietary vitamin A increase intramuscular fat content and polyunsaturated fatty acid proportion in liver from lean pigs. Livestock Science, v.137, p.31-36, 2011. DOI: 10.1016/j. livsci.2010.09.023.

RAUW, W.M.; DIAZ, I.; FRANCÉS, F.; CORELLA, D.; SOLER, J.; TIBAU, J.; GOMEZ-RAYA, L. The relationship between feed intake behaviour with intramuscular fat, cholesterol and fatty acid composition in pork. Journal of Animal Breeding and Genectics, v.129, p.289-297, 2012. DOI: 10.1111/j.14390388.2011.00978.x.

TRAORE, S.; AUBRY, L.; GATELLIER, P.; PRZYBYLSKI, W.; JAWORSKA, D.; KAJAK-SIEMASZKO, K.; SANTÉLHOUTELLIER, V. Higher drip loss is associated with protein oxidation. Meat Science, v.90, p.917-924, 2012. DOI: 10.1016/j. meatsci.2011.11.033.

Received on February 18, 2016 and accepted on September 19, 2016

Pesq. agropec. bras., Brasília, v.52, n.2, p.121-128, fev. 2017

DOI: 10.1590/S0100-204X2017000200006 